\title{
Experimental Study on Chemical Reduction Method to Remove the Chlo- rate Ions in the Water
}

\author{
Xiuguo Lu*, Jianju Duan and Yue Deng
}

School of Civil Engineer and Architecture, East China Jiaotong University, Nanchang, 330013, China

\begin{abstract}
Study on using ascorbic acid and ferrous reduction method to removal the chlorate ions $\left(\mathrm{ClO}_{3}{ }^{-}\right)$in the water. The results show that $100 \mathrm{~mL} 3.06 \mathrm{mg} / \mathrm{L}_{\text {of }} \mathrm{ClO}_{3}{ }^{-}$in ascorbic acid and $\mathrm{ClO}_{3}{ }^{-}$quality ratio $7.19, \mathrm{pH}=6.2,35^{\circ} \mathrm{C}$, the reaction time of for $15 \mathrm{~min}$, the removal rate was $100 \%$. And ferrous reduction method to remove $100 \mathrm{~mL} 3.06 \mathrm{mg} / \mathrm{L} \mathrm{of} \mathrm{ClO}{ }_{3}^{-}$in $\mathrm{pH}=6.2, \mathrm{Fe}^{2+}$ and $\mathrm{ClO}_{3}{ }^{-}$quality ratio $1.79,30^{\circ} \mathrm{C}$ for $30 \mathrm{~min}$, the removal rate was $51 \%$.
\end{abstract}

Keywords: Ascorbic acid, ferrous ion, chlorate ions.

\section{INTRODUCTION}

Since found that the traditional liquid chlorine disinfection has "three to" function will produce organic halogen content, chlorine dioxide was elected the drinking water disinfection substitutes $[1,2]$, chlorine dioxide is a kind of strong oxidizer, sterilization effect is good, almost don't produce in the process of disinfection has "three" effect of halogenated organic content [3]. But recent studies have found that chlorine dioxide disinfection produces $\mathrm{ClO}_{3}{ }^{-}$disinfection by-products. $\mathrm{ClO}_{3}{ }^{-}$toxicological effect is bigger, it can cause hemolytic anemia, and denaturation of hemoglobin for animal blood, may inhibit the role of serum thyroxine, cause fetal cerebellum weight descent, neurobehavioral function slowly or cell number; Will also cause the loss of infant brain weight side effects, etc $[4,5]$. Our country "drinking water health standards" GB5749-2006 regulation in drinking water $\mathrm{ClO}_{3}{ }^{-} \leqq 0.7 \mathrm{mg} / \mathrm{L}[6]$. This article uses the method of chemical reduction of water $\mathrm{ClO}_{3}^{-}$remove the experiments.

\section{INTRODUCTION OF THE EXPERIMENT}

\subsection{Instruments and Reagents}

Instrument: Electronic analytical balance; $\mathrm{HACH}$ ultraviolet spectrophotometer; Color dish; PH meter (PHS-3C); Digital display temperature table; Magnetic stirrer etc.

Reagent: Ascorbic acid; Ammonium ferrous sulfate; Potassium iodide; Sodium hydroxide; Sodium chlorate etc, the above reagents are for AR.

*Address correspondence to this author at School of Civil Engineer and Architecture, East China Jiaotong University, Nanchang, 330013, China;

Tel:+8613970936091; E-mail: 149862562@qq.com

\subsection{The Experimental Steps}

\subsubsection{The Configuration of the Water}

According to take $0.2551 \mathrm{~g} \mathrm{NaClO}_{3}$ in a small amount of water, and then constant volume in $1000 \mathrm{~mL}$ volumetric flask and with the concentration of $200 \mathrm{mg} / \mathrm{L}$ reservior fluid simulation $\mathrm{ClO}_{3}{ }^{-}$water. Experiment used different concentration of $\mathrm{ClO}_{3}{ }^{-}$on the basis of the dilute solution.

\subsubsection{The Experimental Steps}

(1) The method of ascorbic acid

Take a certain concentration of $100 \mathrm{~mL} \mathrm{ClO}_{3}{ }^{-}$in the middle of $250 \mathrm{~mL}$ conical flask, add a certain amount of ascorbic acid chemical reduction experiments, using the single factor variable method, investigate ascorbic acid dosing quantity, $\mathrm{pH}$, initial concentration, reaction temperature and reaction time on the removal rate and the effect of choosing the best processing parameters and experimental mechanism preliminarily.

(2) The method of ferrous salt

Take a certain concentration of $100 \mathrm{~mL} \mathrm{ClO}_{3}{ }^{-}$in the middle of $250 \mathrm{~mL}$ conical flask, add a certain amount of ferrous, static chemical oxidation reduction experiments, using the single factor variable method to investigate ferrous dosing quantity, $\mathrm{pH}$, initial concentration, temperature and reaction time on the removal rate and the effect of preliminary experiment mechanism is discussed in this paper.

\subsubsection{Experimental Results Represent}

Determination of $\mathrm{ClO}_{3}{ }^{-}$by iodine volume method $[7,8]$. The experimental results the $\mathrm{ClO}_{3}{ }^{-}$concentration, the removal rate of $\mathrm{ClO}_{3}{ }^{-}$to characterization. 


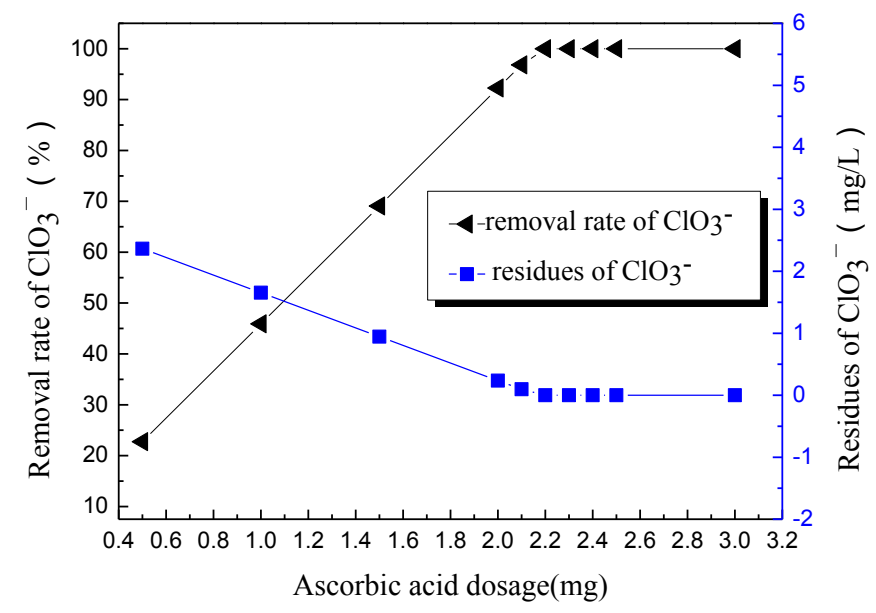

Fig. (1). Influence of dosage on removal rate.

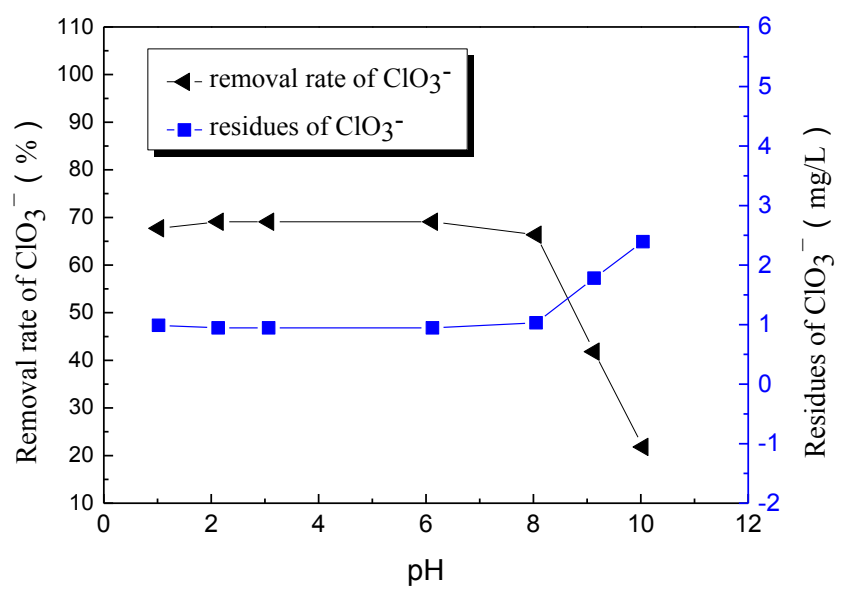

Fig. (2). Influence of $\mathrm{pH}$ on removal rate.

Removal rate: $\mathrm{D} \%=\frac{C_{01} \times C_{e 1}}{C_{01}} \times 100 \%$

Concentration: $\mathrm{C}=\frac{V_{1} \times C_{1}}{V} \times \frac{1}{4} \times 83.46$

$$
\times 1000
$$

Among, $\mathrm{C}_{0}$ and $\mathrm{C}_{\mathrm{e}}$ are respectively before and after the reaction of $\mathrm{ClO}_{3}{ }^{-}$concentration $(\mathrm{mg} / \mathrm{L}) ; \mathrm{V}$ is the volume of water $(\mathrm{mL}) ; \mathrm{V}_{1}$ is consumed by titration sodium thiosulfate standard titration fluid volume $(\mathrm{mL}) ; \mathrm{C}_{1}$ is the concentration of sodium thiosulfate standard titration solution,mol/L; The relative molecular weight of $\mathrm{ClO}_{3}{ }^{-}$is 83.46.

\section{EXPERIMENTAL RESULTS ANALYSIS}

\subsection{Ascorbic Acid on $\mathrm{ClO}_{3}{ }^{-}$Removal Process Research}

\subsubsection{The removal Effect of Quantity}

Take $100 \mathrm{~mL}$ concentration is $3.06 \mathrm{mg} / \mathrm{L} \mathrm{ClO}_{3}{ }^{-}$solution in the middle of $250 \mathrm{~mL}$ volumetric flask of iodine, added $0.5 \mathrm{mg}, 1.0 \mathrm{mg}, 1.5 \mathrm{mg}, 2.0 \mathrm{mg}, 2.0 \mathrm{mg}, 2.2 \mathrm{mg}, 2.3 \mathrm{mg}, 2.4 \mathrm{mg}$,
$2.5 \mathrm{mg}, 3.0 \mathrm{mg}$ ascorbic acid, mixing, waiting for response after $20 \mathrm{~min}$ determines $\mathrm{ClO}_{3}{ }^{-}$concentration in the solution, removing effect as shown in Fig. (1).

Fig. (1) shows, with the increase of ascorbic acid dosing quantity, and the removal rate of $\mathrm{ClO}_{3}{ }^{-}$the trend of increasing, when the additive amount of ascorbic acid $2.2 \mathrm{mg}$ or less, because of the insufficient amount of ascorbic acid, the reaction is incomplete, there is still residual $\mathrm{ClO}_{3}^{-}$at this time. When the additive amount of ascorbic acid $2.2 \mathrm{mg}$, removal rate was stable, and reached $100 \%$, the mass of ascorbic acid and $\mathrm{ClO}_{3}{ }^{-}$ratio 7.19 , reaction completely. So, in the actual process of reaction, in order to achieve the best removal rate, ascorbic acid dosing amount should be controlled in ascorbic acid and $\mathrm{ClO}_{3}^{-}$the extent of the mass ratio of 7.19 or higher.

\subsubsection{The Removal Effect of $\mathrm{pH}$}

Take $100 \mathrm{~mL}$ of initial concentration of $3.06 \mathrm{mg} / \mathrm{L} \mathrm{ClO}_{3}{ }^{-}$solution in the middle of $250 \mathrm{~mL}$ volumetric flask of iodine, adjust the water of the initial $\mathrm{pH}$ value were 1.02, 2.13, 3.07, $6.12,8.05,9.13,10.04$, add $1.5 \mathrm{mg}$ ascorbic acid, fast mixing, stay reaction after $20 \mathrm{~min}$ to determine residual $\mathrm{ClO}_{3}{ }^{-}$concentration in the solution. Remove the effect as shown in Fig. (2). 


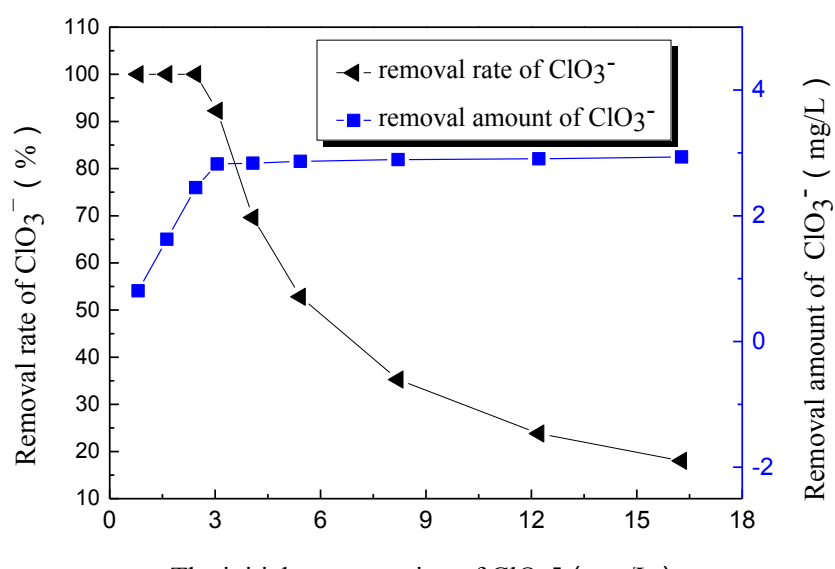

The initial concentration of $\mathrm{ClO}_{3}^{-}(\mathrm{mg} / \mathrm{L})$

Fig. (3). Influence of initial concentration on removal rate.

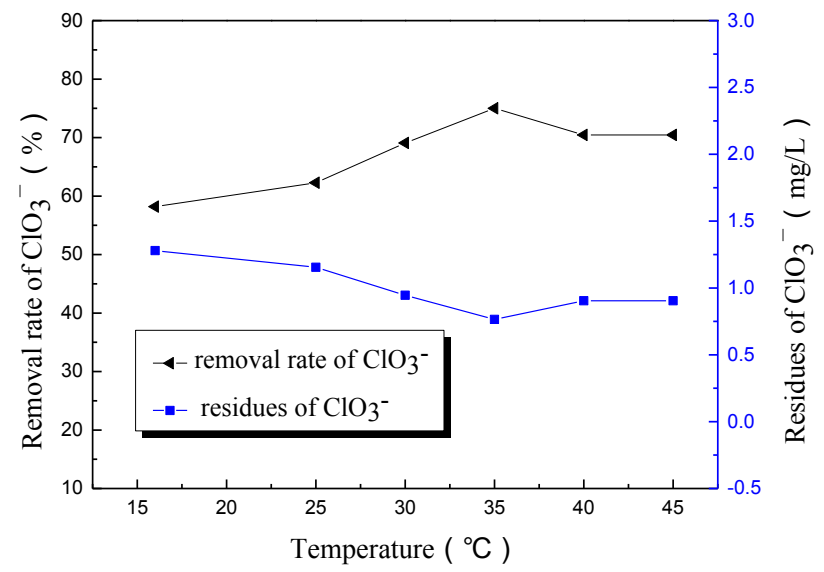

Fig. (4). Influence of temperature on removal rate.

Fig. (2) shows, under the condition of acid, $\mathrm{pH}$ value against bad blood acid removal $\mathrm{ClO}_{3}{ }^{-}$little impact. But when the $\mathrm{pH} 8.0$ or higher, the removal rate of $\mathrm{ClO}_{3}^{-}$fell sharply. This is because the $\mathrm{pH}$ of $\mathrm{ClO}_{3}{ }^{-}$and the REDOX potential of ascorbic acid has a great influence, when $\mathrm{pH} 8.0$ or higher, alkaline, $\mathrm{ClO}_{3}{ }^{-}$oxidizing and reducing of ascorbic acid is reduced, the inhibition of ascorbic acid and $\mathrm{ClO}_{3}{ }^{-}$reaction, so the removal rate decreased. Experimental results comprehensively, select $\mathrm{pH}=6.2$ remove $\mathrm{ClO}_{3}{ }^{-}$best effect.

\subsubsection{The Removal Effect of the Initial Concentration}

Respectively take $100 \mathrm{~mL}$ initial concentration of 0.81 , $1.63,2.45,3.06,4.08,5.42,8.21,12.21,16.27 \mathrm{mg} / \mathrm{L} \mathrm{ClO}_{3}{ }^{-}$ solution in the middle of $250 \mathrm{~mL}$ volumetric flask of iodine, adjusting the solution $\mathrm{pH}=6.2$, add $2 \mathrm{mg}$ ascorbic acid, mixed evenly, quickly to reaction after $20 \mathrm{~min}$ to determine residual $\mathrm{ClO}_{3}{ }^{-}$concentration in the solution. Under the condition of different initial concentration of ascorbic acid removal $\mathrm{ClO}_{3}{ }^{-}$ effect as shown in Fig. (3).

From the change trend of removal rate in Fig (3), ascorbic acid dosing quantity must, initial concentration in 1 to $3 \mathrm{mg} / \mathrm{L}$, high removal rate is mainly due to excessive, ascor- bic acid at this time are the main factors affecting the ascorbic acid dosing quantity.

Dropped from the figure 3 volume change curve, the higher the initial concentration, $\mathrm{ClO}_{3}{ }^{-}$remove the more quantity and curve slope is more and more big, the equilibrium moves to the right, the reaction is more and more fully, when $\mathrm{C}_{0} \geq 3 \mathrm{mg} / \mathrm{L}$ or more, removal amount of $\mathrm{ClO}_{3}{ }^{-}$reached a maximum of $2.9 \mathrm{mg} / \mathrm{L}$. Because the reactant concentration increasing, the activation number of molecules per unit volume increased, per unit time effective collision number increase, the reaction rate is accelerated, can promote balance moves to the right.

\subsubsection{The Removal Effect of the Temperature}

Take $100 \mathrm{~mL}$ concentration is $3.06 \mathrm{mg} / \mathrm{L} \mathrm{ClO}_{3}{ }^{-}$solution in the middle of $250 \mathrm{~mL}$ volumetric flask of iodine, add $1.5 \mathrm{mg}$ ascorbic acid, fast mixing, controlling different reaction temperature $\left(16,25,30,35,40^{\circ} \mathrm{C}\right.$ and $\left.45^{\circ} \mathrm{C}\right)$,stay reaction after 20 min to determine residual $\mathrm{ClO}_{3}{ }^{-}$concentration in the solution. Ascorbic acid at different temperatures to remove $\mathrm{ClO}_{3}{ }^{-}$ the effect of the changes as shown in Fig. (4). 


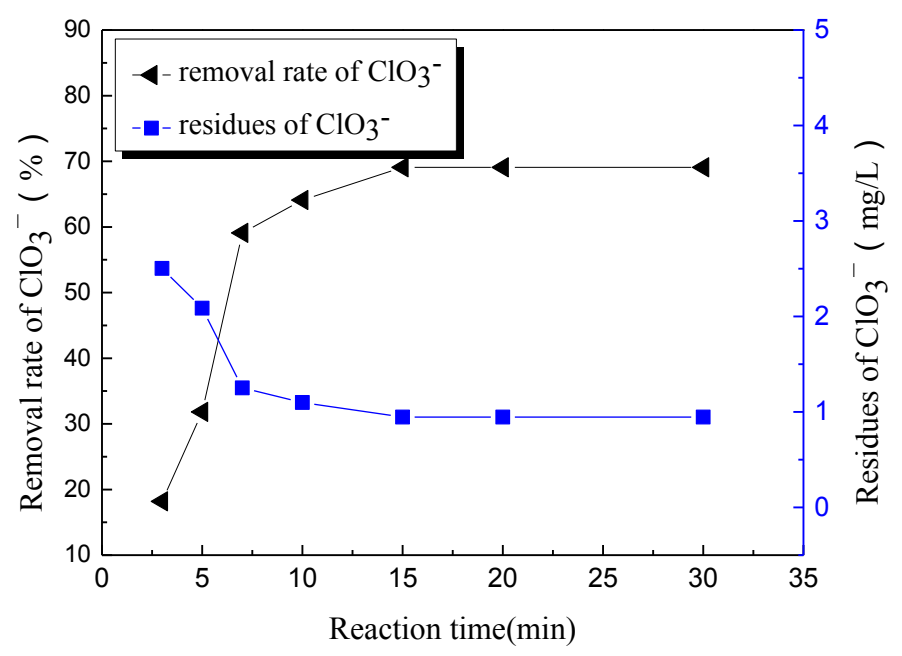

Fig. (5). Influence of response time on removal rate.

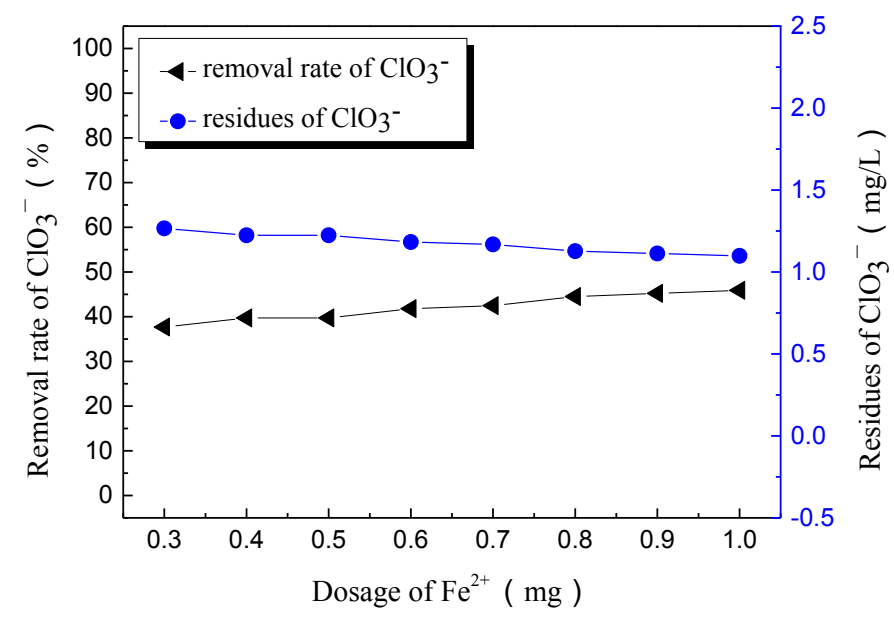

Fig. (6). Influence of dosage on removal rate.

Can be seen from the Fig. (4), temperature against bad blood acid removing $\mathrm{ClO}_{3}{ }^{-}$there is a greater impact. When temperature above $35^{\circ} \mathrm{C}$, with the rapid removal rate of the rise of temperature,this may be due to decomposition of ascorbic acid in the solution.So, in the actual process of reaction, the temperature control in $25 \sim 35^{\circ} \mathrm{C}$ at best.

\subsubsection{The Removal Effect of the Reaction Time}

Take the initial concentration of $3.06 \mathrm{mg} / \mathrm{L} \mathrm{ClO}_{3}{ }^{-} 100 \mathrm{~mL}$ to $250 \mathrm{~mL}$ volumetric flask of iodine solution, add $1.5 \mathrm{mg}$ ascorbic acid, reaction temperature for $28^{\circ} \mathrm{C}$, rapid mixing, controlling different reaction time $(3,5,7,10,15,20,30 \mathrm{~min})$, the determination of residual $\mathrm{ClO}_{3}{ }^{-}$in the final solution concentration. Ascorbic acid removal $\mathrm{ClO}_{3}{ }^{-}$the time effect function is shown in Fig. (5).

Can be seen from the Fig. (5), with the increase of reaction time, removal rate is higher and higher, the residual $\mathrm{ClO}_{3}{ }^{-}$less and less, when the reaction to $15 \mathrm{~min}$ removal rate reached $70 \%$, the removal rate and residual are leveled off, completely basic reaction. So in the actual operation process, the general selection of the optimum reaction time for $15 \mathrm{~min}$.

\subsection{Ferrous Salt on $\mathrm{ClO}_{3}{ }^{-}$Removal Process Research}

\subsubsection{The Removal Effect of Quantity}

Take $100 \mathrm{~mL}$ of initial concentration of $2.03 \mathrm{mg} / \mathrm{L} \mathrm{ClO}_{3}{ }^{-}$ solution in the middle of $250 \mathrm{~mL}$ volumetric flask of iodine, added $0.3 \mathrm{mg}, 0.4 \mathrm{mg}, 0.5 \mathrm{mg}, 0.6 \mathrm{mg}, 0.7 \mathrm{mg}, 0.8 \mathrm{mg}, 0.9 \mathrm{mg}$, $1.0 \mathrm{mg} \mathrm{Fe}{ }^{2+}$, in the $200 \mathrm{r} / \mathrm{min}$, the reaction under $30^{\circ} \mathrm{C}$ for $30 \mathrm{~min}$ after the determination of residual $\mathrm{ClO}_{3}{ }^{-}$concentration in the solution. Under the different $\mathrm{Fe}^{2+}$ dosing quantity $\mathrm{ClO}_{3}{ }^{-}$removal effect as shown in Fig. (6).

By Fig. (6), you can see that with the increase of $\mathrm{Fe}^{2+}$ dosing quantity, the removal rate of $\mathrm{ClO}_{3}^{-}$the trend of increasing, when the additive amount of $\mathrm{Fe}^{2+}$ was $0.8 \mathrm{mg}$, the removal rate was stable, the mass of $\mathrm{Fe}^{2+}$ and $\mathrm{ClO}_{3}^{-} 1.79$. So, in the actual process of reaction, in order to achieve the best removal rate, $\mathrm{Fe}^{2+}$ dosing amount should be controlled in $\mathrm{Fe}^{2+}$ and $\mathrm{ClO}_{3}{ }^{-}$mass ratio of 1.79 or higher.

\subsubsection{The Removal Effect of $\mathrm{pH}$}

Take $100 \mathrm{~mL}$ of initial concentration of $2.03 \mathrm{mg} / \mathrm{L} \mathrm{ClO}_{3}^{-}$ solution in the middle of $250 \mathrm{~mL}$ volumetric flask of iodine, 


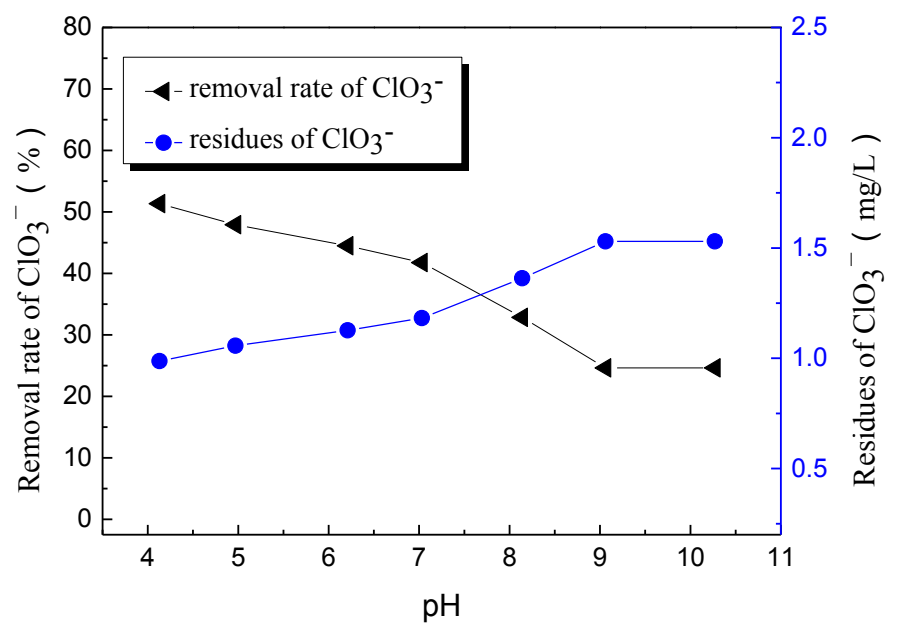

Fig. (7). Influence of $\mathrm{pH}$ on removal rate.

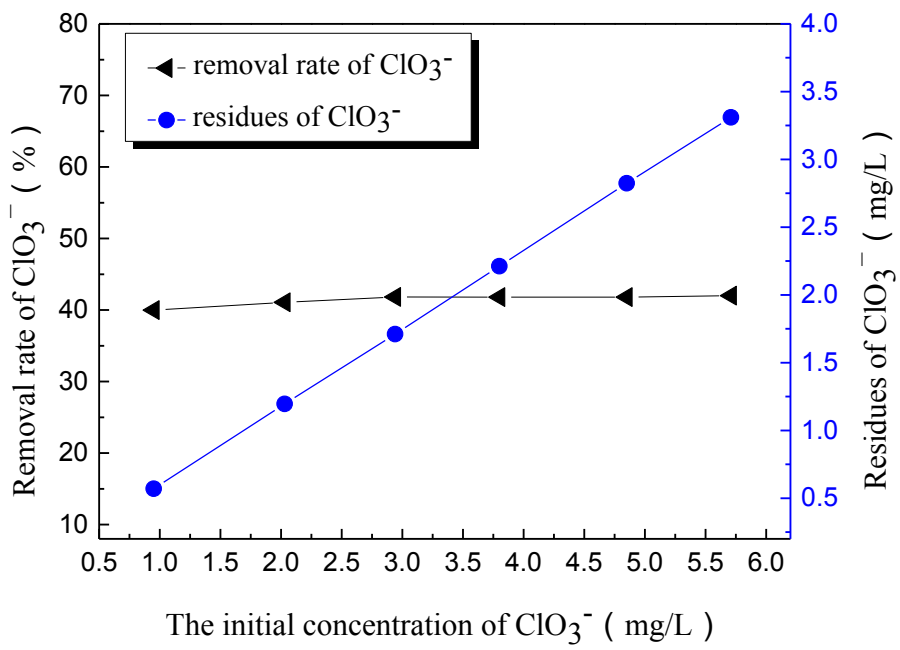

Fig. (8). Influence of initial concentration on removal rate.

adjust the water of the initial $\mathrm{pH}$ value were 4.13,4.97, $6.21,7.03,8.14,9.06$ and 10.27 , joined $0.8 \mathrm{mg} \mathrm{Fe}{ }^{2+}$, in $200 \mathrm{r} / \mathrm{min}$, the summer temperature under $30^{\circ} \mathrm{C}$ for $30 \mathrm{~min}$ after the determination of residual $\mathrm{ClO}_{3}{ }^{-}$concentration in the solution. Under different $\mathrm{pH}$ conditions $\mathrm{Fe}^{2+}$ removal $\mathrm{ClO}_{3}{ }^{-}$ effect as shown in Fig. (7).

As can be seen from the Fig. (7), the $\mathrm{pH}$ of the influence of $\mathrm{Fe}^{2+}$ removal $\mathrm{ClO}_{3}{ }^{-}$is bigger. The smaller the $\mathrm{pH}$, the better the results of the removal of $\mathrm{ClO}_{3}{ }^{-}$. This is mainly because under acid condition, $\mathrm{Fe}^{2+}$ has the strong reducibility, promoted the $\mathrm{Fe}^{2+}$ and $\mathrm{ClO}_{3}{ }^{-}$reaction. At the same time, with the increase of $\mathrm{pH}$ of $\mathrm{Fe}^{2+}$ and $\mathrm{ClO}_{3}^{-}$quality ratio was between 1.53 1.66, and the greater the $\mathrm{pH}$ mass ratio is larger, also this is mainly because the greater the $\mathrm{pH}$ in decreasing the reducibility of $\mathrm{Fe}^{2+}$. Experimental results comprehensively, selecting $\mathrm{pH}=6.2$ remove $\mathrm{ClO}_{3}^{-}$the best comprehensive effect.

\subsubsection{The Removal Effect of the Initial Concentration}

Respectively take $100 \mathrm{~mL}$ initial concentration of 0.95 , $2.03,3.80,4.85,5.71 \mathrm{mg} / \mathrm{L} \mathrm{ClO}_{3}{ }^{-}$solution in the middle of
$250 \mathrm{~mL}$ volumetric flask of iodine, press $\mathrm{Fe}^{2+} / \mathrm{ClO}_{3}{ }^{-}=3$ quality than adding the $\mathrm{Fe}^{2+}$, in the $200 \mathrm{r} / \mathrm{min}$, the summer temperature under $30^{\circ} \mathrm{C}$ for $30 \mathrm{~min}$ after the determination of residual $\mathrm{ClO}_{3}{ }^{-}$concentration in the solution. Under the condition of different initial concentration of $\mathrm{Fe}^{2+}$ removal $\mathrm{ClO}_{3}^{-}$ effect as shown in Fig. (8).

From Fig. (8) removal rate change trend, $\mathrm{Fe}^{2+} / \mathrm{ClO}_{3}{ }^{-}=3$, initial concentration in $1 \sim 6 \mathrm{mg} / \mathrm{L}$, the initial concentration effect on the removal rate is very weak, the experimental results show that in low concentration, as long as the control quality of $\mathrm{Fe}^{2+}$ and $\mathrm{ClO}_{3}^{-}$and all other things being equal, $\mathrm{ClO}_{3}{ }^{-}$removal rate is almost not affected by initial concentration.

\subsubsection{The Removal Effect of the Temperature}

Take $100 \mathrm{~mL}$ of initial concentration of $2.03 \mathrm{mg} / \mathrm{L} \mathrm{ClO}_{3}{ }^{-}$ solution in the middle of $250 \mathrm{~mL}$ volumetric flask of iodine, add $0.8 \mathrm{mg} \mathrm{Fe}{ }^{2+}$, mixing, controlling different reaction temperature $\left(25^{\circ} \mathrm{C}, 35^{\circ} \mathrm{C}, 45^{\circ} \mathrm{C}\right.$ and $\left.55^{\circ} \mathrm{C}, 65^{\circ} \mathrm{C}, 75^{\circ} \mathrm{C}\right)$, reaction under $200 \mathrm{r} / \mathrm{min} 30 \mathrm{~min}$ after the determination of residual 


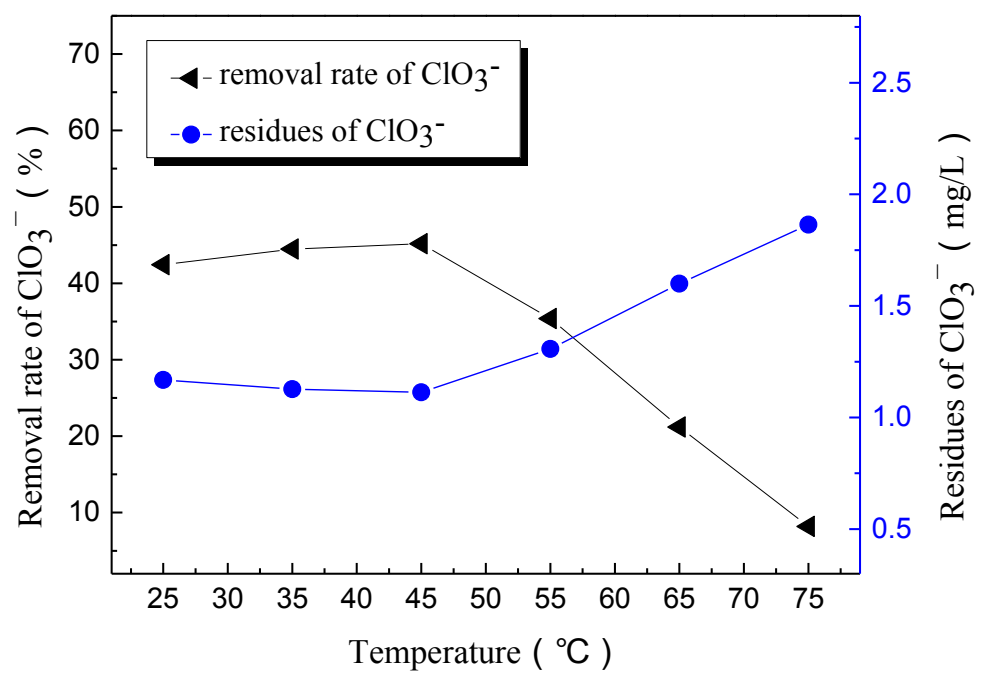

Fig. (9). Influence of temperature on removal rate.

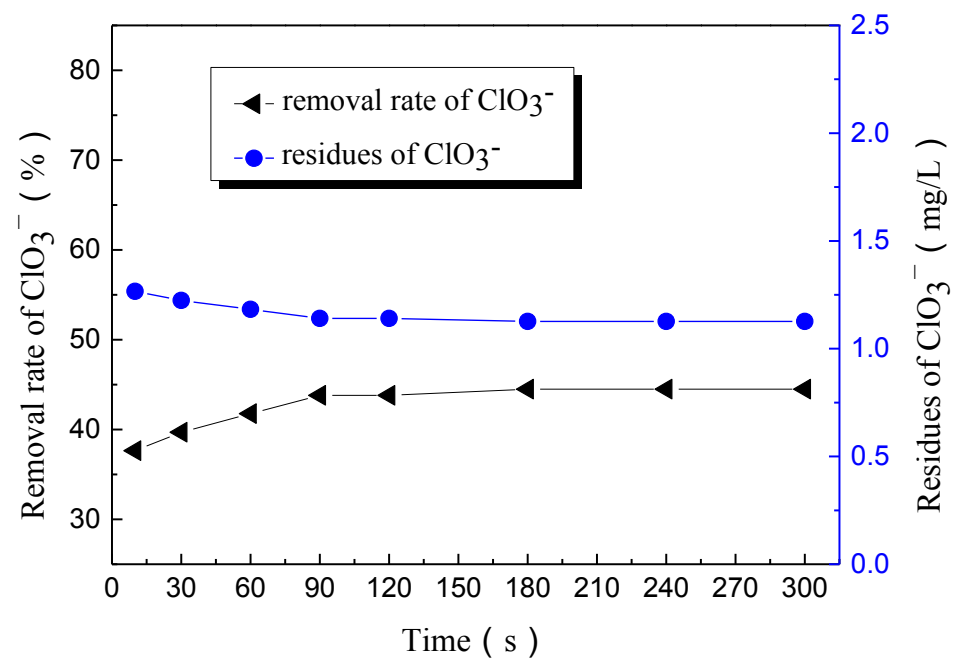

Fig. (10). Influence of response time on removal rate.

$\mathrm{ClO}_{3}{ }^{-}$concentration in the solution. Different temperatures of $\mathrm{Fe}^{2+}$ removal $\mathrm{ClO}_{3}{ }^{-}$effect as shown in Fig. (9).

Can be seen from the Fig. (9), the temperature of $\mathrm{Fe}^{2+}$ removal $\mathrm{ClO}_{3}{ }^{-}$is a greater impact. $\mathrm{ClO}_{3}{ }^{-}$removal rate increased with the increasing of temperature slowly,but when the temperature reaches $45^{\circ} \mathrm{C}$, with removal rate and rapid the rise of temperature,this is due to the reaction of $\mathrm{Fe}^{2+}$ and $\mathrm{ClO}_{3}{ }^{-}$belongs to the endothermic reaction,in a certain temperature range, the rise of temperature of reaction.But when the temperature is above $45^{\circ} \mathrm{C}, \mathrm{Fe}^{2+}$ hydrolysis happens to generate $\mathrm{Fe}(\mathrm{OH})_{3}$. So, in the actual process of reaction, the temperature control in best is $30^{\circ} \mathrm{C}$.

\subsubsection{The Removal Effect of the Reaction Time}

Take the initial concentration of $2.03 \mathrm{mg} / \mathrm{L} \mathrm{ClO}_{3}{ }^{-} 100 \mathrm{~mL}$ to $250 \mathrm{~mL}$ volumetric flask of iodine solution, add $0.8 \mathrm{mg}$ $\mathrm{Fe}^{2+}$, reaction temperature of $30^{\circ} \mathrm{C}$, rapid mixing. Controlling different reaction time $(10 \mathrm{~s}, 30 \mathrm{~s}, 60 \mathrm{~s}, 90 \mathrm{~s}, 120 \mathrm{~s}, 180 \mathrm{~s}, 240 \mathrm{~s}$ and $300 \mathrm{~s}$ ), the determination of residual $\mathrm{ClO}_{3}^{-}$in the final solution concentration. $\mathrm{Fe}^{2+}$ removal $\mathrm{ClO}_{3}^{-}$the time effect function is shown in Fig. (10).

As can be seen from the figure 10 , the reaction of $\mathrm{Fe}^{2+}$ and $\mathrm{ClO}_{3}{ }^{-}$in a few minutes to seconds can completely basic reaction. So in the process of actual operation can save time, generally choose the optimum reaction time for $2 \mathrm{~min}$.

\section{CONCLUSION}

(1) Ascorbic acid removal $\mathrm{ClO}_{3}{ }^{-}$experiments show that the reaction of ascorbic acid and $\mathrm{ClO}_{3}^{-}$speed slow, at the time of $15 \mathrm{~min}$ to basic response completely; Ascorbic acid removal effect of $\mathrm{ClO}_{3}{ }^{-}$as ascorbic acid dosing quantity increases, when the ascorbic acid and $\mathrm{ClO}_{3}{ }^{-} 7.19$ removal rate was $100 \%$, while the quality of response completely; And relationship with the $\mathrm{pH}$ of the water body will decrease, 
$\mathrm{pH}=6.2$ remove $\mathrm{ClO}_{3}{ }^{-}$the best effect; With the increase of temperature $\mathrm{ClO}_{3}{ }^{-}$remove immediately after the first rise is reduced, the temperature control in $25^{\circ} \mathrm{C} \sim 35^{\circ} \mathrm{C}$ best; The higher the initial concentration, fully some reaction, but $\mathrm{ClO}_{3}{ }^{-}$bad blood acid removal $\mathrm{ClO}_{3}{ }^{-}$influenced by initial concentration are faint.

(2) $\mathrm{Fe}^{2+}$ removal $\mathrm{ClO}_{3}{ }^{-}$experiments show that the reaction of $\mathrm{Fe}^{2+}$ and $\mathrm{ClO}_{3}{ }^{-}$quickly and completely in $2 \mathrm{~min}$ to the basic reaction; $\mathrm{Fe}^{2+}$ of $\mathrm{ClO}_{3}{ }^{-}$removal effect with ascorbic acid dosing quantity increases, and relationship with the water samples of $\mathrm{pH}$ value will decrease, $\mathrm{pH}=6.2$ remove $\mathrm{ClO}_{3}{ }^{-}$ the best effect; With the increase of temperature $\mathrm{ClO}_{3}{ }^{-}$remove immediately after the first rise is reduced, the temperature control in $25^{\circ} \mathrm{C} \sim 45^{\circ} \mathrm{C}$ best; The higher the initial concentration, fully some reaction, but $\mathrm{ClO}_{3}^{-}$bad blood acid removal $\mathrm{ClO}_{3}{ }^{-}$influenced by initial concentration are faint.

(3) According to the experimental results compared the removal effect of ascorbic acid and $\mathrm{Fe}^{2+}$, ascorbic acid of $\mathrm{ClO}_{3}{ }^{-}$removing effect is better, can be used as a reductant preference.

\section{CONFLICT OF INTEREST}

The authors confirm that this article content has no conflicts of interest.

\section{ACKNOWLEDGEMENTS}

This work is supported by the national natural science and technology fund, China (No.51168013) and national science and technology support project, China (No.2014BAC04B03).

\section{REFERENCES}

[1] J. L. Huang, S. F. Li,C. W. Cui, et al. "The research progress of drinking water disinfectant $\mathrm{ClO}_{2}$," Journal of Harbin construction university, vol. 34,no. 5,pp. 39-43,2001

[2] J. Q. Liu, H. C. Bai, et al. "The nature of chlorine dioxide, preparation and application," Chinese Journal of Disinfection, 2010-27(3).

[3] Z. L. You, J. S. Zhang, R. B. Hui, et al. "Chlorine dioxide purification by-products of the control and removal techniques," Water supply and drainage, 2003-17.

[4] L. Wang, J. L. Huang, et al. " $\mathrm{ClO}_{2}$ disinfection by-products of the inorganic and purify," Harbin institute of technology, Municipal environmental engineering institute.2002, 1002-1124- 03 .

[5] L. Wang, J. L. Huang, H. B. Li, C. L. Li, et al. "The water $\mathrm{ClO}_{2}$, $\mathrm{Cl}_{2}, \mathrm{ClO}_{2}{ }^{-}$and $\mathrm{ClO}_{3}{ }^{-}$continuous determined by iodine volume method," The journal of Harbin construction university, 1997 (04).

[6] Ministry of Health of the People's Republic of China,China national standardization management committee. Life health standards. Beijing: China Standards Press, 2007.

[7] Y. Q. Yang, C. C. Tang, et al. "The characteristics of granular activated carbon to remove chlorine dioxide disinfection residue study," Journal of east China jiaotong university, 1996 (02).

[8] J. K. Zhang, X. J. Liu, et al. "The five step of chlorine dioxide each reaction component content determination in water by iodine volume method approach to improve water," China's environmental microbiology, 2011-28-01.

Received: September 16, 2014

Revised: December 23, 2014

Accepted: December 31, 2014

(C) Lu et al.; Licensee Bentham Open.

This is an open access article licensed under the terms of the Creative Commons Attribution Non-Commercial License (http://creativecommons.org/licenses/by$\mathrm{nc} / 3.0 /$ ) which permits unrestricted, non-commercial use, distribution and reproduction in any medium, provided the work is properly cited. 